\title{
IDENTIFIKASI PENERAPAN PENDEKATAN SAINTIFIK KEGIATAN MENANYA (M2) KURIKULUM 2013 DALAM PROSES PEMBELAJARAN MATEMATIKA YANG BERSIFAT TEACHER CENTERED LEARNING
}

\author{
Etty Octaviani Manalu' ${ }^{1}$, Haryanto ${ }^{2 *}$, Andi F Wyrasti ${ }^{3}$, Petrus Juli ${ }^{4}$ \\ 1, 2,3 Jurusan Pendidikan Matematika, Universitas Papua \\ Jalan Gunung Salju, Amban Manokwari, Papua Barat, Indonesia \\ ${ }^{4}$ SMA YPK Immanuel Manokwari \\ Jalan Aru, Manokwari Tim, Kabupaten Manokwari, Papua Barat, Indonesia \\ e-mail: ${ }^{2}$ harry_mat_unipa@yahoo.com;
}

corresponding author*

\begin{abstract}
This research aims to identify the application of scientific approaches of 2013 curriculum in mathematics learning process which is TCL (Teacher Centered Learning).This is a qualitative research. Data collecting technique of this research was observation of the learning process, interview conducted to the teacher and also students and documentation in the form of video recording during learning. The data analysis technique that used in this research was qualitative descriptive analysis. Based on the results of this research we identified a scientific approach second activities Asking (M2) then divided again into 6 indicators and 22 descriptors. At the first learning was obtain 5 indicators and 8 descriptors during the learning process. Then at the second learning was obtain 6 indicators and 15 descriptors during the learning process.
\end{abstract}

Keywords: scientific approach, asking, 2013 curriculum, teacher centered learning

\section{Pendahuluan}

Kurikulum 2013 merupakan kurikulum yang berlaku dalam sistem pendidikan Indonesia saat ini. Kurikulum ini merupakan kurikulum yang diterapkan oleh pemerintah untuk menggantikan Kurikulum 2006 yaitu Kurikulum Tingkat Satuan Pendidikan (KTSP) yang telah berlaku selama kurang lebih 6 Tahun. Siti Halimah (2014) mengemukakan salah satu alasan perubahan KTSP ke Kurikulum 2013 yaitu banyaknya kalangan yang menilai bahwa KTSP 2006 merupakan kurikulum yang memberatkan peserta didik, karena isi dan pesan-pesan masih terlalu padat yang ditunjukkan dengan banyaknya mata pelajaran dan banyak materi keluasan dan kesukarannya melampaui tingkat perkembangan usia anak. Kurikulum 2013 dikatakan merupakan penyempurnaan dari KTSP.

Salah satu pendekatan pembelajaran yang digunakan dalam Kurikulum 2013 adalah pendekatan saintifik. Berdasarkan Peraturan Menteri Pendidikan dan Kebudayaan Tahun 2019 Perihal Perubahan dan Istilah pada Kurikulum 2013 Tahun Pelajaran 2018/2019 butir ke 4 dikatakan bahwa pendekatan saintifik yang terdiri dari kegiatan Mengamati, Menanya, Mencoba, Menalar, dan Mengomunikasikan (5M) bukanlah satu-satunya pendekatan yang wajib digunakan saat mengajar dan tidak harus berurutan.

Menurut Hosnan (2014) pendekatan saintifik adalah suatu proses pembelajaran yang dirancang supaya peserta didik secara aktif mengkonstruk konsep, hukum atau prinsip melalui kegiatan mengamati, merumuskan masalah/ hipotesis, mengumpulkan data dengan berbagai teknik, menarik kesimpulan dan mengkomunikasikan hasil pengamatan. Pendekatan saintifik adalah pendekatan yang menggunakan langkah-langkah serta kaidah ilmiah dalam proses pembelajaran. Berdasarkan paparan diatas maka pendekatan saintifik merupakan pendekatan dalam proses pembelajaran yang menggunakan langkah-langkah atau kaidah-kaidah ilmiah yang mencakup mengamati, menanya/ merumuskan masalah, mengumpulkan informasi, mengasosiasi/ mengolah informasi dan mengkomunikasikan.

Sistem pembelajaran di sekolah cenderung bersifat satu arah, yaitu pemberian materi oleh guru atau lebih dikenal dengan Teacher Centered Learning (TCL). Pembelajaran tersebut membuat peserta didik menjadi pasif karena hanya mendengar materi sehingga kreativitas mereka akan cenderung terpupuk. Pada sistem 
pembelajaran TCL guru lebih banyak melakukan kegiatan belajar-mengajar dengan bentuk ceramah (Aan \& Munadi, 2015). Hal ini berbanding terbalik dengan prinsip pembelajaran dalam kurikulum 2013 yang menekankan pada aktivitas peserta didik. Pembelajaran pada Kurikulum 2013 lebih memusatkan pada kegiatan peserta didik, hal ini juga didukung dengan isi buku pelajaran Kurikulum 2013 yang lebih menekankan keaktifan peserta didik, sehingga materi atau buku tidak hanya menjadi bahan bacaan semata (Paparan Wamendik, 2014)

Hasil studi pendahuluan di SMA YPK Immanuel sebagai sekolah yang telah menggunakan Kurikulum 2013, menunjukkan bahwa terdapat beberapa hal yang mengganjal dari penerapan Kurikulum 2013 ini. Hal-hal tersebut diantaranya, pada saat proses pembelajaran masih sangat nampak penerapan TCL atau pembelajaran yang berpusat pada guru, padahal seharusnya hal tersebut dapat diminimalisir dalam Kurikulum 2013 karena ciri dari Kurikulum 2013 menekankan pada SCL atau pembelajaran yang berpusat pada peserta didik. Kemudian, peneliti juga melihat bahwa peserta didik cenderung pasif dalam proses pembelajaran yang berlangsung. Hal ini disebabkan karena, peserta didik hanya bertindak sebagai penerima ilmu selama proses pembelajaran dan ilmu diberikan langsung oleh guru tersebut.

Berdasarkan hasil pengamatan yang diperoleh peneliti selama kurang lebih 2 minggu tersebut mendorong peneliti untuk mengkaji lebih lanjut mengenai penerapan pendekatan saintifik Kurikulum 2013 di SMA YPK Immanuel Manokwari. Oleh karena itu, penelitian ini mengidentifikasi penerapan pendekatan saintifik Kurikulum 2013 dalam proses pembelajaran matematika yang bersifat TCL. Fokus dari penelitian ini adalah mengidentifikasi kegiatan menanya pada proses pembelajaran tersebut.

\section{Metode Penelitian}

Penelitian ini merupakan penelitian kualitatif. Dalam penelitian ini pengambilan data dilakukan dengan cara mengobservasi proses pembelajaran, mewawancarai guru dan siswa. Penelitian ini dilakukan di SMA YPK Immanuel Manokwari pada Tahun 2020.

\section{Hasil dan Pembahasan}

\subsection{Hasil}

Proses Pembelajaran Pertemuan Pertama
Kegiatan saintifik kedua yakni menanya, terdapat 6 indikator yang terbagi lagi dalam beberapa deskriptor. Penjelasan mengenai muncul pendekatan saintifik pada M2, sebagai berikut:

a. Mengajukan Pertanyaan (M21)

Ketika proses pembelajaran berlangsung salah satu peserta didik terlihat mengajukan pertanyaan kepada guru terkait materi yang diajarkan (M214). Adapun hal ini dapat dilihat pada cuplikan transkrip video pertemuan pertama berikut.

Tabel 1. Keterangan Singkatan/ Istilah

\begin{tabular}{|l|l|l|}
\hline No & Simbol & Keterangan \\
\hline 1 & G & Guru \\
\hline 2 & SPD & Semua Peserta didik /Pebelajar \\
\hline 3 & PD 1, PD 2 & $\begin{array}{l}\text { Peserta didik /Peserta didik 1, } \\
\text { Peserta didik /Peserta didik 2 }\end{array}$ \\
\hline 4 & SSPD & $\begin{array}{l}\text { Salah Satu Peserta didik } \\
\text { /Pebelajar }\end{array}$ \\
\hline 5 & P & Penanya \\
\hline 6 & S1, S2, S3 & Subjek 1, Subjek 2, Subjek 3 \\
\hline
\end{tabular}

\section{PD 2 : Pak mau tanya (Mengangkat tangan) (merespon dengan gerakan, menit: 40.43), kalau yang ada angka 1 atau angka 3 itu diubah lagi kah? (mengajukan pertanyaan, Menit : 40.44 - 40.51) \\ G : (Menjawab pertanyaan PD) Itu namanya konstan. Atau bahasa lainnya sama dengan $\mathrm{C}$, yakni konstan tidak diubah. Tetap}

b. Mengemukakan fakta dan prinsip (M22)

Peserta didik terlihat tidak mengemuka-kan fakta yang terkait dengan materi, juga fakta yang bertentangan dengan materi pelajaran dan tidak mengemukakan prinsip yang terkait dengan materi. Peserta didik terlihat merumuskan pertanyaan terkait materi dari penjelasan guru (M224). Ada hal unik yang ditemukan perihal mengajukan pertanyaan pada saat proses pembelajaran berlangsung, yakni ada salah satu PD yang beralasan tidak mengajukan pertanyaan karena menganggap pertanyaan dari teman sudah cukup mewakili. Berikut transkrip hasil wawancara dengan salah satu PD.

$$
\begin{array}{lll}
\mathrm{P} & : & \text { Pada saat pembelajaran apakah kamu } \\
& \text { memberikan pertanyaan? } \\
\mathrm{S} & : & \text { Tidak, karena teman lain sudah } \\
& \text { memberikan pertanyaan dari situ pak } \\
& & \text { guru sudah jelaskan, jadi darisitu sudah } \\
& \text { mengerti } \\
\mathrm{P} & : & \text { Jadi pertanyaan dari teman sudah cukup? } \\
\mathrm{S} & : & \text { Iya } \\
\mathrm{P} & : & \text { Tapi seandainya kamu tidak mengerti } \\
& \text { pasti kamu bertanya? }
\end{array}
$$


S3 : Iya, pasti bertanya

c. Mengemukakan pendapat (M23)

Salah satu PD terlihat mengemukakan pendapatnya terkait materi dari penjelasan guru (M231). Berikut cuplikan transkrip video pembelajaran pertemuan pertama.

PD 2 : Pak, ini kalau diganti berarti 3 kali 5 toh. (Mengemukakan pendapat, menit: 48.09) (menunjuk kearah papan tulis) (Merespon dengan gerakan, menit: 48.11)

G : Tidak tau, itu jawabanmu, ayo kerjakan (guru memberi kesempatan PD untuk menyampaikan hasil pengamatannya (soal))

\section{d. Mendiskuiskan (M24)}

Peserta didik terlihat melakukan tanya jawab dengan teman sebangku (M241). Berikut cuplikan transkrip video pembelajaran pertemuan pertama

PD 1,2 : (Beberapa orang peserta didik nampak mencatat dan mendiskusikan soal yang diberikan oleh guru dengan teman sebangku) (Mencatat, menit 57.04 dan Mendiskusikan pelajaran dengan teman sebangku, menit : 57.41- 58.01)

Lalu, peserta didik juga terlihat melakukan tanya jawab dengan guru pada (M242). Berikut cuplikan transkrip video pembelajaran pertemuan pertama.

G : 2,71 itu darimana ? (bertanya kepada PD yang menjawab)

(Terjadi tanya jawab antara guru dan PD, menit : 58.04 - 59.19)

PD 2 : (Teman sebangku PD1 yang menjawab 2,71) dari 19 dibagi 7

G : (Memastikan jawaban peserta didik dengan menghitung) Ok betul.

Dari penjelasan guru, PD mampu merumuskan pertanyaan yang berkaitan dengan materi pelajaran pada menit 40.44 sampai 48.09 (M243). Lebih lengkap dapat dilihat pada transkrip video pembelajaran pertemuan pertama pada lampiran.

e. Interupsi (M25)

Hasil observasi pembelajaran pertemuan pertama PD terlihat tidak melakukan semua kegiatan pada indikator interupsi (M25). PD juga tidak menyetujui pendapat PD lain, yang akhirnya akan diluruskan oleh guru.

\section{f. Mengajukan saran (M26)}

Ketika proses pembelajaran, guru tak jarang memberikan saran. Begitupun pada pertemuan pertama ini, pada saat guru memberikan saran, PD memperhatikan saran yang diberikan guru (M261). Berikut cuplikan transkrip video pembelajaran pertemuan pertama.

G : Tetap (terhenti sejenak, sambil melihat kembali buku ajar) Kalau misalnya $\lim _{x \rightarrow 2}\left(x^{2}-1\right)$ (menulis dipapan) yang 1 ini yang disebut dengan konstan, ditulis saja tidak bisa diubah karena tidak ada variabel $\mathrm{x}$ untuk mensubstitusi nilai pendekatan, maka tidak dikerjakan tinggal ditulis ulang saja (menganggukan kepala dan memberikan nada penekanan)

SPD : (PD memperhatikan saran yang diberikan guru, menit: 41.16-41.58)

Peserta didik juga menyetujui saran yang diberikan guru pada menit 41.49 (M262). Berikut cuplikan transkrip video pembelajaran pertemuan pertama.

G : Iya, ditulis saja 1, kalau 0 berarti 0 , yang dibelakang-belakang nilai konstan tidak bisa diubah-ubah diikutkan saja sampai selesai (menggerakan spidol), bisa?

SPD : (PD menyetujui saran yang diberikan oleh guru, menit 41.49)

\section{Proses Pembelajaran Pertemuan Kedua}

Kegiatan saintifik kedua yakni menanya, terdapat 6 indikator yang akan terbagi lagi dalam beberapa deskriptor. Penjelasan mengenai muncul pendekatan saintifik pada M2, sebagai berikut:

a. Mengajukan Pertanyaan (M21)

Ketika proses pembelajaran berlangsung, salah satu peserta didik terlihat mengajukan pertanyaan kepada guru terkait materi yang diajarkan dengan kata lain (M214). Adapun hal ini dapat dilihat pada cuplikan transkrip video pertemuan kedua berikut.

PD 1 : Pak, 16 darimana? (tanya salah satu peserta didik sambil menunjuk jawaban dipapan tulis) (mengajukan pertanyaan dan merespon dengan gerakan, menit : $19.01-19.04$ )

b. Mengemukakan fakta dan prinsip (M22)

Peserta didik terlihat tidak mengemukakan fakta yang terkait dengan materi, juga fakta yang bertentangan dengan materi pelajaran dan tidak mengemukakan prinsip yang terkait dengan materi. Peserta didik terlihat merumuskan pertanyaan terkait materi dari penjelasan guru (M224).

c. Mengemukakan pendapat (M23)

Peserta didik terlihat mengemukakan pendapatnya terkait materi dari penjelasan guru 
(M231). Berikut cuplikan transkrip video pembelajaran pertemuan kedua.

\begin{tabular}{|c|c|c|}
\hline PD 3 & : & $\begin{array}{l}\text { B (melihat kecontoh b) (mengemukakan } \\
\text { pendapat terkait materi, menit : } 11.37 \text { ) }\end{array}$ \\
\hline $\mathrm{G}$ & : & eh, (melihat kearah papan tulis) yang b? \\
\hline PD 4 & & $\begin{array}{l}\text { (peserta didik lain) bukan b, tapi c } \\
\text { (mengemukakan pendapat terkait } \\
\text { materi, menit: } 11.45 \text { ) }\end{array}$ \\
\hline PD 5 & • & $\begin{array}{l}\text { (PD lainnya ) yang } \mathrm{b}, \mathrm{b} \text { (mengemukakan } \\
\text { pendapat terkait materi) }\end{array}$ \\
\hline G & & $\begin{array}{l}\text { (melihat kearah papan tulis dengan } \\
\text { pandangan yang kurang yakin) yang } \\
\text { mana? (melihat ke pebelajar) }\end{array}$ \\
\hline PD 6 & & $\begin{array}{l}\text { Yang b pak (mengemukakan pendapat } \\
\text { terkait materi, menit: } 11.57 \text { ) }\end{array}$ \\
\hline G & & Yang b (berjalan kearah papan tulis)? \\
\hline PD 2 & & $\begin{array}{l}\text { (peserta didik lain) yang d pak. } \\
\text { (mengemukakan pendapat } \\
\text { materi, menit: } 12.14-12.16 \text { ) }\end{array}$ \\
\hline
\end{tabular}

Peserta didik juga nampak menanggapi pendapat peserta didik laninya (M232). Berikut cuplikan transkrip video pembelajaran pertemuan kedua.

PD 1 : Pak, 16 darimana? (tanya salah satu peserta didik sambil menunjuk jawaban dipapan tulis) (mengajukan pertanyaan dan merespon dengan gerakan, menit : $19.01-19.04$ )

PD 4 : Kau yang tadi bilang 16 baru (salah satu PD memberikan pendapat/ menyela pendapat temannya tadi, menit : 19.05)

PD 1 : Jih, saya bilang nanti hasilnya 16 (sambil menunjuk dan memutar badan mengarah kepada teman yang menyela pendapatnya, menit: 19.07) hasil terakhirnya (ada pergerakan kepala seperti mengangguk, menit: 19.08 dan tangan yang tetap menunjuk kepapan tulis)

Setelah terjadi perbedaan pendapat antara PD1 dan PD4, Guru berusaha menengahi perbedaan pendapat begitu juga terlihat bahwa PD2 berusaha menengahi pendapat temannya (M233). Berikut cuplikan transkrip video pembelajaran pertemuan kedua.

$$
\begin{array}{ll}
\text { G } & \text { Oh begitu (Berusaha menengahi } \\
& \text { perbedaan pendapat antara PD) } \\
\text { PD 1 : } & \text { Iya pak (mengangguk, menit: } 19.15) \\
\text { PD 2 : } & \begin{array}{l}
\text { Sama saja 2 (menengahi perbedaan } \\
\text { pendapat menunjuk kearah papan tulis, } \\
\text { menit: 19.15) }
\end{array}
\end{array}
$$

Beberapa momen dalam pembelajaran PD terlihat merumuskan pendapat terkait materi pelajaran (M234). Peserta didik terlihat menyetujui pertanyaan yang diberikan oleh guru (M235), untuk ditindak lanjuti atau diselesaikan. Berikut cuplikan transkrip video pembelajaran pertemuan kedua.
G : Sekarang kita bikin banyak-banyak soal, limit (memberikan soal latihan, menit: 09.28 - 10.15). Contoh limit yang pertama atau a. $\lim _{x \rightarrow 2} 2 x^{3}$ kemudian $b$. $\lim _{x \rightarrow 0} x \quad$ kemudian c. $\lim _{x \rightarrow-1} 2 x$ kemudian d. $\lim _{x \rightarrow 3} 4$. Sekarang salah satu dari kalian melihat rumus yang kita buat tadi, dan ada contoh soal disampingnya

SPD : (PD menyetujui pertanyaan yang diberikan untuk di kerjakan, menit: 10.25)

\section{d. Mendiskuiskan (M24)}

Peserta didik terlihat melakukan tanya jawab dengan teman sebangku (M241). Berikut cuplikan transkrip video pembelajaran pertemuan kedua.

$$
\begin{array}{lll}
\text { G } & : & \text { Eh, baca cepat. (menit: 05.16) } \\
\text { PD 4 : } & \text { (Sebelum menjawab, PD sempat } \\
& \text { berdiskusi dengan teman yang ada } \\
& \text { dibelakang Lalu, menjawab tetapi } \\
& \text { dengan cara yang salah dan bergumam, } \\
& \text { menit: 05.30-05.35) } \\
& : \text { Iya (menunjuk ke peserta didik yang } \\
\text { duduk didepan) } & \text { (Yang ditunjuk) 23 itu (menjawab } \\
\text { n } & \text { namun dengan suara pelan dan terlihat } \\
\text { berdiskusi dengan teman sebangku, } \\
\text { menit 17.40) }
\end{array}
$$

PD juga terlihat melakukan tanya jawab dengan guru (M242). Berikut cuplikan transkrip video pembelajaran pertemuan kedua.

(Terjadi tanya jawab antar guru dan PD, menit: $15.48-16.03)$.

$$
\begin{array}{lll}
\text { G } & : \text { Contoh mana yang tidak mempunyai } \\
& \text { variabel (Bertanya, menit 15.48)? } \\
\text { SSPD }: & \text { Contoh d } \\
\mathrm{G} & : \text { Kenapa contoh d? eh? } \\
\text { PD 2 }: & \text { Karena tidak memiliki variabel } \\
& \text { (menjawab dengan ragu dan } \\
& \text { menggerakan tangan, Mengemukakan } \\
& \text { pendapat, menit: 16.03). } \\
& \text { (Menunjuk salah satu pebelajar) Kau, } \\
\text { Genapa? } & \text { (yang ditunjuk) karena tidak memiliki } \\
& \text { variabel pak (mengemukakan pendapat } \\
& \text { menit: 16.13) }
\end{array}
$$

Peserta didik terlihat merumuskan pertanyaan terkait materi dari penjelasan guru (M243). Pada proses pembelajaran guru juga yang memberikan pertanyaan berupa soal kepada PD untuk diselesaikan.

\section{e. Interupsi (M25)}

Peserta didik terlihat menyela penjelasan atau peserta didik lainnya (M251). Berikut 
cuplikan transkrip video pembelajaran pertemuan kedua.

$\begin{array}{ll}\text { PD } 4: & \text { Kau yang tadi bilang } 16 \text { baru (salah satu } \\ & \text { PD memberikan pendapat/ menyela } \\ & \text { pendapat temannya tadi, menit: 19.05) } \\ \text { G : } & \text { (Melanjutkan penjelasannya) } \\ \text { PD 2 : } & \text { (Menyela perkataan guru, padahal guru } \\ & \text { sedang berbicara kepada PD, menit: } \\ & \text { 20.06) Pak? }\end{array}$

Salah satu peserta didik tidak setuju dengan penjelasan guru (M252). Hal ini dikarenakan oleh guru keliru dalam menyelesaikan contoh soal yang diberikan. Berikut cuplikan transkrip video pembelajaran kedua.

\begin{tabular}{|c|c|c|}
\hline G & & $\begin{array}{l}\text { (Sepertinya salah mendengar jawaban } \\
\text { pebelajar) } 16 \times 2=32\end{array}$ \\
\hline PD 1 & : & $\begin{array}{l}\text { (melihat dengan tidak yakin dan ada } \\
\text { yang menggerakan tangan seakan } \\
\text { memastikan jawaban) }\end{array}$ \\
\hline G & . & 32 (menunjuk jawaban di papan tulis) \\
\hline PD 1 & : & $\begin{array}{l}\text { Pak, } 16 \text { darimana? (tanya salah satu } \\
\text { peserta didik sambil menunjuk jawaban } \\
\text { dipapan tulis) } \\
\text { (mengajukan pertanyaan dan merespon } \\
\text { dengan gerakan, menit: } 19.01-19.04 \text { ) }\end{array}$ \\
\hline
\end{tabular}

Peserta didik menyetujui atau setuju dengan penjelasan atau pendapat peserta didik lainnya terkait jawaban atau penyelesaian soal yang diberikan, sehingga guru menuliskan jawaban baru (M253). Berikut cuplikan transkrip video pembelajaran pertemuan kedua.
SPD : (Menyetujui pendapat PD 1, menit: 19.33)
G : $8 \times 2$ (menuliskan jawaban baru)

f. Mengajukan saran (M26)

Ketika proses pembelajaran, guru tak jarang memberikan saran. Begitupun pada pertemuan kedua, pada saat guru memberikan saran, PD memperhatikan saran yang diberikan guru (M261). Berikut cuplikan transkrip video pembelajaran pertemuan kedua.
G : Oh begitu. $2 \times 2 \times 2$. Kalau lupa lagi maka kembali lagi ke rumus umum namanya $\mathrm{a}^{2}=\mathrm{a}$. a (Guru memberikan saran terkait pelajaran, menit: 18.10 18.25). Jadi setiap ada seperti ini, kembali kerumus umum-rumus umum (membuat penekanan suara dan penekanan gerakan tangan) Jadinya seperti itu

Disela-sela saran guru (seperti diatas) peserta didik juga menyetujui saran yang diberikan guru (M262). Berikut cuplikan transkrip video pembelajaran pertemuan kedua.

SPD : (Disela saran guru, PD menyetujui saran yang diberikan guru dengan merespon berupa anggukan pada menit 18.20)

Ketika pembelajaran berlangsung, PD tidak memberikan saran terkait materi pelajaran yang diberikan. Hasil wawancara dengan beberapa PD menunjukkan bahwa ternyata PD lebih suka bila guru yang memberikan semua materi pelajaran. Berikut hasil wawancara dengan beberapa PD.

P : Menurut kamu, lebih suka guru mengajar dengan metode ceramah atau berkelompok? Alasannya?

S1 : Lebih baik kalau dalam belajar itu kita dituntun oleh pak guru, karena kalau misalnya kita berkelompok belum tentu kita punya pemahaman itu sama dengan guru, jadi kita juga takut salah, namanya juga murid masih belajar, jadi kita juga masih butuh bimbingan

P : Kamu suka dipandu sama guru atau cari sendiri informasi terkait materi?

S2 : Lebih baik dipandu oleh bapak, karena kita belum tau materi yang akan diajarkan akan seperti apa

P : Menurut kamu pada saat pembelajaran, bapak berperan penuh tidak?

S3 : Iya

$\mathrm{P} \quad$ : Tapi kamu suka pembelajaran seperti itu? Alasannya?

S3 : Suka, karena kita kan belum tahu apaapa jadi harus pak guru yang memberikan materi agar kita bisa tahu)

Tabel 2. Rangkuman Kegiatan Menanya (M2)

\begin{tabular}{|c|c|c|c|c|c|}
\hline \multirow{2}{*}{ Indikator } & \multirow{2}{*}{ Deskriptor } & \multicolumn{2}{|c|}{ Pertemuan 1} & \multicolumn{2}{|c|}{ Pertemuan 2} \\
\hline & & $\mathrm{Ya}$ & Tidak & Ya & Tidak \\
\hline \multirow{4}{*}{$\begin{array}{l}\text { Mengajukan } \\
\text { pertanyaan (M21) }\end{array}$} & 1. Dengan kata apa (M211) & & $\checkmark$ & & $\checkmark$ \\
\hline & 2. Dengan kata mengapa (M212) & & $\checkmark$ & & $\checkmark$ \\
\hline & 3. Dengan kata bagaimana (M213) & & $\checkmark$ & & $\checkmark$ \\
\hline & 4. Dengan kata lain (M214) & $\checkmark$ & & $\checkmark$ & \\
\hline \multirow{4}{*}{$\begin{array}{l}\text { Mengemukakan } \\
\text { fakta atau prinsip } \\
\text { (M22) }\end{array}$} & 1. Mengemukakan fakta (M221) & & $\sqrt{ }$ & & $\checkmark$ \\
\hline & $\begin{array}{l}\text { 2. Mengemukakan fakta bertentangan } \\
\text { (M222) }\end{array}$ & & $\checkmark$ & & $\checkmark$ \\
\hline & 3. Mengemukakan prinsip (M223) & & $\checkmark$ & & $\checkmark$ \\
\hline & 4. Merumuskan pertanyaan (M224) & $\checkmark$ & & $\checkmark$ & \\
\hline
\end{tabular}




\begin{tabular}{|l|l|l|l|l|l|}
\hline \multirow{3}{*}{$\begin{array}{l}\text { Mengemukakan } \\
\text { pendapat (M23) }\end{array}$} & 1. Mengemukakan pendapat (M231) & $\checkmark$ & & $\checkmark$ & \\
\hline & 2. Menanggapi pendapat (M232) & & $\checkmark$ & $\checkmark$ & \\
\hline & 3. Menengahi pendapat (M233) & & $\checkmark$ & $\checkmark$ & \\
\hline & 4. Merumuskan pendapat (M234) & & $\checkmark$ & $\checkmark$ & \\
\hline & 5. Menyetujui pertanyaan (M235) & & $\checkmark$ & $\checkmark$ & \\
\hline \multirow{5}{*}{$\begin{array}{l}\text { Mendiskusikan } \\
\text { M24) }\end{array}$} & $\begin{array}{l}\text { 1. Melakukan tanya jawab dengan teman } \\
\text { (M241) }\end{array}$ & $\checkmark$ & & $\checkmark$ & \\
\hline & $\begin{array}{l}\text { 2. Melakukan tanya jawab dengan guru } \\
\text { (M242) }\end{array}$ & $\checkmark$ & & $\checkmark$ & \\
\hline & 3. Merumuskan pertanyaan (M243) & $\checkmark$ & & $\checkmark$ & \\
\hline \multirow{5}{*}{ Interupsi (M25) } & 1. Menyela (M251) & & $\checkmark$ & $\checkmark$ & \\
\hline & 2. Tidak setuju (M252) & & $\checkmark$ & $\checkmark$ & \\
\hline & 3. Menyetujui (M253) & & $\checkmark$ & $\checkmark$ & \\
\hline \multirow{2}{*}{$\begin{array}{l}\text { Mengajukan saran } \\
\text { (M26) }\end{array}$} & 1. Memperhatikan saran (M261) & $\checkmark$ & & $\checkmark$ & \\
\hline & 2. Menyetujui saran (M262) & $\checkmark$ & & $\checkmark$ & \\
\hline & 3. Mengajukan saran (M263) & & $\checkmark$ & & $\checkmark$ \\
\hline
\end{tabular}

Berdasarkan tabel 2 diatas, maka terlihat bahwa pada pertemuan pertama 5 indikator dan 8 deskriptor teridentifikasi selama proses pembelajaran pertemuan pertama. Sedangkan pada pertemuan kedua, terlihat seluruh atau 6 indikator dan 15 deskriptor yang terlihat selama proses pembelajaran pertemuan kedua.

\subsection{Pembahasan}

Menurut Kemdikbud (2013:18) kegiatan menanya berfungsi membangkitkan rasa ingin tahu, minat dan perhatian pebelajar tentang suatu tema atau pembelajaran, mendorong dan menginspirasi pebelajar untuk aktif belajar serta mengembangkan pertanyaan dari dan untuk dirinya. Selaras dengan penjelasan sebelumnya menurut Sani (2014) kegiatan menanya sangat penting untuk meningkatkan keingintahuan dalam diri pebelajar dan mengembangkan kemampuan pebelajar untuk belajar sepanjang hayat.

Penerapan pendekatan saintifik kegiatan menanya pada pembelajaran pertemuan pertama terlihat dari 6 indikator dan 22 deskriptor, hanya 4 indikator dan 8 deskriptor yang terlihat muncul pada proses pembelajaran pertemuan pertama. Adapun indikator dan deskriptor tersebut yakni indikator mengajukan pertanyaan (M21) dengan deskriptor menanya dengan kata lain (M214). Indikator mengemukakan fakta atau prinsip (M22) dengan deskriptor merumuskan pertanyaan (M224). Indikator mengemukakan pendapat (M23) dengan deskriptor mengemukakan pendapat (M231). Indikator mendiskusikan (M24) dengan deskriptor melakukan tanya jawab dengan teman (M241), melakukan tanya jawab dengan pembelajar (M242) serta merumuskan pertanyaan (M243). Indikator mengajukan saran (M26) dengan deskriptor memperhatikan saran (M261) serta menyetujui saran (M262) yang terlihat mucul pada proses pembelajaran.
Lain halnya dengan pertemuan kedua. Penerapan pendekatan saintifik pada pembelajaran pertemuan kedua terlihat lebih baik, hal ini dibuktikan dengan munculnya 6 indikator dan 15 deskriptor. Adapun indikator dan deskriptor tersebut adalah indikator mengajukan pertanyaan (M21) dengan deskriptor dengan kata lain (M214). Indikator mengemukakan fakta atau prinsip (M22) dengan deskriptor merumuskan pertanyaan (M224). Indikator mengemukakan pendapat (M23) dengan deskriptor mengemukakan pendapat (M231), menanggapi pendapat (M232), menengahi pendapat (M233), merumuskan pendapat (M234) dan menyetujui pendapat (M235). Indikator mendiskusikan (M24) dengan deskriptor melakukan tanya jawab dengan teman (M241), melakukan tanya jawab dengan pembelajar (M242) serta merumuskan pertanyaan (M243). Indikator interupsi (M25) dengan deskriptor menyela (M251), tidak setuju (M252) dan menyetujui (M253). Terakhir, indikator mengajukan saran (M26) dengan deskriptor memperhatikan saran (M261) serta menyetujui saran (M262) yang terlihat mucul pada proses pembelajaran.

Sedangkan deskriptor yang tidak muncul pada pertemuan pertama yaitu: pada indikator M21 yaitu dengan kata apa (M211), dengan kata mengapa (M212), dengan kata bagaimana (M213). Pada indikator mengemukakan fakta atau prinsip (M22) yaitu mengemukakan fakta (M221), mengemukakan fakta bertentangan (M222), dan mengemukakan prinsip (M223). Pada indikator mengemukakan pendapat (M23) yaitu menanggapi pendapat (M232), menengahi pendapat (M233), merumuskan pendapat (M234) dan menyetujui pertanyaan (M235). Pada indikator interupsi (M25) yaitu menyela (M251), tidak setuju (M252) dan menyetujui (M253). Terakhir indikator mengajukan saran yaitu mengajukan saran (M263). 
Deskriptor yang tidak muncul pada pertemuan kedua adalah pada indikator M21 yaitu dengan kata apa (M211), dengan kata mengapa (M212), dengan kata bagaimana (M213). Pada indikator mengemukakan fakta atau prinsip (M22) yaitu mengemukakan fakta (M221), mengemukakan fakta bertentangan (M222), dan mengemukakan prinsip (M223). Terakhir indikator mengajukan saran yaitu mengajukan saran (M263).

Berdasarkan paparan diatas menunjukkan bahwa dengan pembelajaran TCL penerapan pendekatan saintifik Kurikulum 2013 kegiatan menanya pada pertemuan pertama teridentifikasi 5 indikator dengan 8 deskriptor. Kemudian dengan pembelajaran TCL penerapan pendekatan saintifik Kurikulum 2013 kegiatan menanya pada pertemuan kedua teridentifikasi 6 indikator dan 15 deskriptor.

\section{Kesimpulan}

Berdasarkan hasil dan pembahasan diatas maka dapat disimpulkan bahwa pada pembelajaran yang masih TCL penerapan pendekatan saintifik kegiatan Menanya (M2) terlihat pada saat pembelajaran berlangsung. Hal ini dapat ditunjukkan pada pertemuan pertama terlihat 5 Indikator dan 8 deskriptor. Selanjutnya, pada pertemuan kedua terlihat 6 Indikator dan 15 deskriptor yang terlihat selama proses pembelajaran berlangsung. Hanya saja dibeberapa kesempatan, guru yang masih TCL masih sering tidak menyadari akan munculnya saintifik kegiatan menanya ini.

\section{Daftar Pustaka}

Daryanto. (2014). Pendekatan Pembelajaran Saintifik Kurikulum 2013. Yogyakarta: Gava Media.

Halimah, Siti. (2014) Telaah Kurikulum. Medan: Perdana Publishing.

Hosnan, M. (2014). Pendekatan Saintifik dan Kontekstual dalam Pembelajaran Abad 21. Bogor: Ghalia Indonesia.

Mulyasa. (2014). Pengembangan dan Implementasi Kurikulum 2013. Bandung: Remaja Rosdakarya.

Musfiqon \& Nurdyansyah. (2015). Pendekatan Saintifik. Sidoarjo: Naizamia Learning Center.

Perdata, Ida Bagus. (2016). Instrumen Observasi Kegiatan Inti Pembelajaran Matematika Berbasis Pendekatan Sintifik (5M) di SMA. Jurnal Santiaji Pendidikan, 4(2), 139-142.

Pusat Kurikulum. (2013). Konsep Pendekatan Ilmiah (Saintifik). Jakarta: Kementrian Pendidikan dan Kebudayaan.

Sani, Abdullah Ridwan. (2014). Pembelajaran Saintifik Untuk Implementasi Kurikulum 2013. Jakarta: Bumi Aksara. 